EGU2020-4598

https://doi.org/10.5194/egusphere-egu2020-4598

EGU General Assembly 2020

(c) Author(s) 2020. This work is distributed under

the Creative Commons Attribution 4.0 License.

\title{
Paleomagnetism on salt-detached syndiapiric overburden rocks from the Northern margin of the Basque-Cantabrian extensional Basin (N Spain)
}

\author{
Elisabet Beamud ${ }^{1,2}$, Ruth Soto ${ }^{3}$, Charlotte Peigney ${ }^{2,4}$, Eduard Roca ${ }^{2,4}$, and Emilio Luis Pueyo ${ }^{3}$ \\ ${ }^{1}$ Paleomagnetic Laboratory, CCITUB - ICTJA CSIC, Barcelona, Spain (betbeamud@ub.edu) \\ ${ }^{2}$ Geomodels UB Research Institute, University of Barcelona, Barcelona, Spain \\ ${ }^{3}$ Instituto Geológico y Minero de España, Zaragoza, Spain \\ ${ }^{4}$ Dpt. Dinàmica de la Terra i de l'Oceà, University of Barcelona, Barcelona, Spain
}

The Basque-Cantabrian Basin is a hyperextended extensional basin that formed as the result of the opening of the Bay of Biscay at latest Jurassic-middle Cretaceous times. It is formed by upper mantle and crustal rocks affected by both high- and low-angle faults that die against an Upper Triassic salt layer that decouples the deformation and generate salt diapirs. From late Santonian (Late Cretaceous), the Basque-Cantabrian Basin was involved in the Pyrenean orogeny which reactivated the previous faults and salt décollement.

In this scenario, our study focuses at the northern margin of this basin where the salt overburden (Jurassic to Eocene in age) is displaced several km northwards and appears compartmentalized by several salt walls (Bakio, Bermeo, Guernica and Mungia diapirs). These walls are linked by narrow stripes of variable orientations in which the overburden appears strongly deformed by tight detachment folds and minor thin-skinned thrusts. The piercing salt is composed of Upper Triassic evaporites, red clays and volcanic ophites, and is flanked by Aptian-Albian syn-diapiric carbonate to terrigenous halokinetic sequences limited by angular unconformities that become conformable as distance to the diapir edges increases. Using a paleomagnetic study, we seek to better understand the kinematics of suprasalt deformation trying to detect and quantify vertical axis rotations recorded during both the extensional and later contractional reactivation of the basin margin. For that, 52 paleomagnetic sites have been analyzed in the overburden sequence. Of these, 50 sites were sampled in Aptian, Albian and Cenomanian marls, marly limestones and fine grained sandstones, and 2 sites were sampled in Eocene sandstones and marly limestones. Characteristic components are usually defined between $200-450{ }^{\circ} \mathrm{C}$ pointing to titanomagnetite as the main remanence carrier. They show predominant anticlockwise rotations with some anomalous clockwise and larger anticlockwise rotations near the salt diapirs. All these components yield normal polarity, as expected by the age of the rocks, which (except the Eocene sites) coincide with the Cretaceous superchron C34n. However, some of the sites are clearly remagnetized as they yield negative fold tests, whereas some other sites show a prefolding magnetization. These results are also supported by several hysteresis analyses and back field experiments that confirm a clear remagnetization signal in the Day diagram in part of the studied 
rocks. However, the spatial location of remagnetized rocks does not show a distinct structural pattern. With the current data, the origin and age of this remagnetization is difficult to assess and further analysis will be necessary. It could be either an earlier Albian-Maastrichtian remagnetization or a remagnetization linked to the Pyrenean compression. Although these uncertainties, the obtained results allow establishing a preliminary kinematic model for the suprasalt deformation together with the underlying decoupled autochtonous materials. 